\title{
Study on International Trade Tax Competition Problems under Regional Economy
}

Burenmende

School of economics and management, Inner Mongolia University for the Nationalities, Tongliao, 028000, China

Keywords: regional economy, international trade, tax, competition, problems

\begin{abstract}
With the gradual opening of socioeconomic environment, countries start to communicate frequently and tax competition problems among countries are gradually revealed. This paper analyzes the current situation of tax competition in ASEAN-China Free Trade Area, puts forward problems in tax competition among the member countries, and further gives solutions to these problems.

Western scholars have long studied on tax competition problems with main research direction of tax competition among local governments in a closed economy. At current stage, the trend of regional economic integration has been presented and being constantly strengthened, while the world economy shows imbalanced development. This paper, in combination with ASEAN-China Free Trade Area, studies on international trade tax competition problems under regional economy.
\end{abstract}

\section{Current situation of tax competition in ASEAN-China Free Trade Area}

(I) Economic closeness

After the burst of Asian Financial Crisis, the Southeast Asia generally suffered serious losses. In this financial crisis, China refused to depreciate the RMB, played the role of a responsible power, and thus reduced corresponding influence from the financial crisis to a certain degree. This practice of China was also greatly agreed by surrounding countries. China had been cooperating well with ASEAN countries in terms of both politics and economy, and reached an agreement with ASEAN in January 1, 2010 to formally establish the ASEAN-China Free Trade Area. After this area was set up, some member countries applied tax preference and tax reduction \& exemption policies, resulting in influence of malignant tax on this Free Trade Area.

(II) Investment contact

So far, ASEAN-China Free Trade Area basically contains developing countries, and thus there is less foreign investment. Tax competition between China and ASEAN generally refers to competition in tax preference. Compared with ASEAN countries, China has quite skilled labor market and excellent political and economic environment, and thus has significant advantages in attracting foreign investment by this way. China has abundant resources, and thus resource-oriented investment is prone to influence of tax. The ASEAN is also attracting resource-oriented investment and has inevitably tax competition with China. Although China and ASEAN are economically complementary and realize common development, they have fierce competition as well and the Free Trade Area would also intensify such competition.

(III) Tax competition

At present, the ASEAN-China Free Trade Area has tax competition modes mainly including reduction of exchange rate and tax preference policies. The latter is widely used and can be mainly divided into direct tax preference and indirect tax preference. Current tax preference measures of China are: "unity of both inside and outside" tax preference policy, and some self-employment projects could offset the investment amount with taxable income amount; and carry out tax reduction and exemption policy for some key national projects.

\section{Problems in tax competition among member countries in ASEAN-China Free Trade Area}

As countries need to attract international investment, many ASEAN countries increase 
preference of tax policies, and make full use of tax preference policies to encourage foreign investment, so as to promote coordinated regional development. This situation forms a competition among taxes for China, and enough importance shall be attached.

(I) Fierce tax competition relations among member countries

Since the 1980s, all countries have been carrying out a series of economic development policies, including China such as opening up and export etc. A main influencing factor of foreign investment is the costs of productivity. China and the ASEAN have relatively low productivity costs, and thus attract almost the same amount of investment and have fierce competition in terms of tax preference.

Currently, ASEAN countries have not a large market scale, and are quite decentralized. Importance is attached to resource and cost advantages when foreign investment enters the ASEAN, and tax preference is a major influencing factor of foreign investment. Tax competition is realized by lowering corporate income tax rate among member countries, and such tax competition would corrode tax base of other countries and distort resource allocation. Some countries have more preferential tax policies than other countries in order to attract more talents and investment, which would affect normal operation of talents and capital and further damage interests of other member countries.

Since the launch of ASEAN-China Free Trade Area, each ASEAN country needs a lot of advanced technologies and sufficient funds to develop national economy, and thus issues a series of preference policies, among which tax policy is quite important. With fierce competition among countries, a harmful tax competition is formed, giving a chance for some illegal companies, as some transnational corporations make use of such tax competition among member countries of ASEAN to evade tax and transfer profits by certain means.

(II) Less rigorous tax information

The ASEAN has serious tax problems, specifically including:

1. The ASEAN fails to grasp tax information of each member country systematically and comprehensively, and has relatively less information and insufficient storage.

2. A tax information network is not formed among member countries to provide quite detailed and adequate tax information.

3. There is not symmetrical tax information between the government and some foreign-related enterprises and thus a transfer and communication bridge could not be established. As a result, enterprises could only find tax policies and dynamics of the government on their own.

(III) Absence of a sound settlement mechanism for international tax disputes

Tax involves a lot of aspects, which mainly including national sovereignty. In international trade, tax disputes would often happen. At current stage, ASEAN-China Free Trade Area hasn't a sound institution that can settle tax disputes. As a result, in case of tax disputes among countries, between the government and enterprises and between foreign-related enterprises and domestic enterprises, both sides could only negotiate or solve with rights of country. This is unfair from the perspective of law.

\section{Solutions to tax competition problems among member countries of ASEAN-China Free Trade Area}

ASEAN-China Free Trade Area is established to reduce or eliminate tariffs and non-tariffs to a certain degree and promote the content of cooperation rationally according to certain steps and time, which is an inevitable process of regional economic integration. During regional economic integration, one precondition is to strengthen tax coordination of Free Trade Area to avoid harmful tax competition among member countries, so as to promote free flow of personnel, capital and goods etc in the area effectively.

(I) Strengthen tax coordination of Free Trade Area, and avoid harmful tax competition among member countries effectively

China could highly recommend establishing a high-level tax research institute with members selected from tax researchers, scholars and experts of member countries to mainly study on a series 
of tax policies of China and ASEAN countries, focus on tax coordination problem among countries, and report research findings to governments of member countries for reference, so as to avoid harmful tax competition effectively.

In modern society, economy develops constantly. Under the general trend of regional economic integration and economic globalization, member countries of the Free Trade Area shall increase vigorously investment in construction of soft environment, and change tax preference policies gradually into enhancement of national treatment.

(II) Optimize China's tax preference policies

China has currently entered the economic times which is technology-led, and thus shall use tax preference competitive policies for innovation and development of high technologies, which shall focus on analysis of costs and effectiveness of tax preference policies.

For instance, the overall investment environment is very important and strongly competitive in attraction of investment, because China has a large market, relatively low labor costs and a good resource condition. If the return on investment of an industry is above $20 \%$, it would be a key investment project for foreign merchants even if there isn't tax preference, and tax preference actually means profits besides return on investment for foreign enterprises, in which context it is very difficult to reveal the competitive and stimulating role of tax preference.

Thus, preferential tax rate (mainly indirect) shall be carried out for domestic enterprises and industries with less specific investment or competition.

(III) Avoid harmful regional tax competition

Current Chinese tax preference policies are carried out according to international conventions, and include many adverse ones. In this case, after-tax preference shall be unified and simplified as soon as possible, and tax preference of industries that shall be attended such as some western areas with poor investment environment and some special industrial areas shall be retained during the implementation of this policy, based on which industrial structure shall be adjusted appropriately and special preference shall be reduced gradually to mainly include industrial preference supplemented by regional preference. Such preference mechanism could generate lasting effects. It shall also be noted that international coordination of tax preference policies shall be more concerned while insisting on tax sovereignty and harmful international tax competition shall be effectively avoided.

Tax competition is a game or combat, in which the final winners are developed countries as capital exporting countries, and these countries have many counteracting factors in terms of tax preference that may lead to huge losses of tax revenue and possible falling of policies.

So, it is necessary for developing countries like China in a position of capital importing country with great interest in tax measures to coordinate through a series of negotiation mechanisms, take a clear position, avoid risks of malignant tax, cater to new international tax rules, take actions by means specified in these rules, and thus guarantee tax rights and interests of China and some other developing countries.

In current tide of economic globalization, more rules and policies on international tax shall be established and implemented. Under such a situation, we shall seize actively such favorable tax policies for developing countries like China and promote the formation and implementation of standard policies vigorously.

(IV) China shall give play to its leading role and coordinate international tax

After joining the WTO, economy of member countries of the Free Trade Zone is more closely related to world economy, and tax policy would still play a critical role in attracting foreign investment, change direct preference into indirect preference to a greater extent, overturn previous regional preference and change into policies that mainly include industrial preference.

Member countries of the Free Trade Area attract foreign investment generally by tax policies and thus face fierce tax competition. In this case, it becomes very urgent to strengthen tax coordination among member countries. In the Free Trade Area, China is a power that could play a leading role in strengthening international trade coordination of ASEAN-China Free Trade Area.

In terms of international tax competition and preference, China shall start from the low level, 
carry out a preference combat to be advantageous, develop some tax rate and tax preference policies, and promote unilateral preference into international tax coordination, and thus implement tax policies from a higher level. This could eliminate negative influence of international tax competition on China, ensure tax rights and interests of China under regional economy and improve its overall economic level.

\section{Conclusions}

Social economy is developing constantly, and international trade tax competition also becomes an international problem of concern. International trade tax competition would certainly bring influence to interests of sovereign nations, and malignant tax competition would lead to huge impacts on economy of such sovereign nations. In front of these problems, governments of all countries shall be concerned, and the World Economic Organization and theory circle shall also think about this and seek corresponding methods and measures.

\section{References}

[1] Wang Xuqi. WTO and Rights of Economic Man [A]. Beijing Forum (2011) Harmony of Civilization and Common Prosperity—the Traditional and the Modern, Reform and Transformation: “WTO and Development of China after Joining WTO for Ten Years” WTO Roundtable Conference Papers and Abstract Book [C], 2011.

[2] Song Yulan. Reflection on Problems in "ASEAN-China Free Trade Area” [A]. Collected Works (Vol. 6) of Survey of Party School Office of Chinese Academy of Social Sciences on Conditions of Border Regions in Guangxi Zhuang Autonomous Region, the $33^{\text {rd }}$ Class for Advanced Studies of Party School of Chinese Academy of Social Sciences [C], 2009.

[3] Xu Yan. Coordination of Non-resident Corporate Investment Income and International Tax Conventions in the Law of Corporate Income Tax [A]. Collected Papers of 2007 Annual Conference and the Fifth National Academic Symposium on Finance and Tax Law by Institute of Finance and Tax Law of China Law Society [C], 2007.

[4] Research Group of Jilin Provincial Institute of International Taxation, Tang Zhiping, Li Xianglong, Yu Haijun, Zheng Zhiyong, Zhang Qingli. Current Situation of ASEAN-China Tax Coordination and Policy Recommendations [J]. International Taxation in China, 2008 (04).

[5] Hao Chunhong. Comment on China's New “Corporate Income Tax" System-Analysis from Perspectives of Economic Globalization, Economics and Accounting System [J]. Contemporary Finance \& Economics, 2008 (12). 